\title{
SOSIALISASI INOVASI MEDIA PEMBELAJARAN PERMAINAN TUNAS INTEGRITAS UNTUK PERKEMBANGAN ANAK USIA DINI DI PAUD KASIH BUNDA YULIANI KEC. ILIR BARAT I
}

\author{
Padilah $^{1}$, Febriyanti Utami ${ }^{2}$, Melinda Puspita Sari Jaya ${ }^{3}$, Santa Idayana Sinaga ${ }^{4}$, \\ Rahmah Novianti ${ }^{5}$, Romadona Noverina ${ }^{6}$ \\ Program Studi Pendidikan Guru PAUD Universitas PGRI Palembang \\ email: padilahutama@gmail.com ${ }^{1}$, febriyantiutami90@gmail.com ${ }^{2}$, santashmily@gmail.com ${ }^{3}$, \\ melindaps05@gmail.com ${ }^{4}$, aliciarahma@gmail.com ${ }^{5}$,romadonanoverina71@gmail.com ${ }^{6}$
}

\begin{abstract}
Abstrak
Pengabdian kepada masyarakat ini bertujuan untuk melaksanakan tri dharma perguruan tinggi, merealisasikan program kerja Program Studi Pendidikan Guru PAUD, FKIP, Universitas PGRI Palembang dan memberikan sosialisasi mengenai permainan tunas integritas yang dapat menjadi inovasi bagi pendidik PAUD dalam memilih permaian ataupun mengembangkan bentuk permainan bagi anak. Permainan yang disosialisaikan dalam kegiatan ini yaitu Permainan Tunas Integritas dengan judul "Keranjang Bolong". Permainan Tunas Integritas ini merupakan salah satu program pendidikan karakter (antikorupsi) untuk jenjang pendidikan anak usia dini (PAUD) yang dikembangkan oleh Anti-Corruption Learning Centre (ACLC) Pendidikan dan Pelayanan Masyarakat (Dikyanmas) Komisi Pemberantasan Korupsi (KPK). Kegiatan pengabdian kepada masyarakat ini menggunakan beberapa metode, yaitu metode ceramah, metode demontrasi, dan metode tanya jawab. Melalui kegiatan sosialiasi yang dilakukan, peserta mendapatkan referensi mengnai jenis-jenis permainan yang dapat digunakan dalam menstimulasi keenam aspek perkembangan anak dan mengembangkan pendidikan karakter sejak usia dini.
\end{abstract}

Kata Kunci: Sosialisasi, Permainan Tunas Integritas, Perkembangan Anak Usia Dini

\begin{abstract}
This community service aims to carry out the tri dharma of higher education, realize the work program of PAUD Teacher Education, FKIP, Palembang PGRI University Program and provide information about the game of integrity shoots that can be an innovation for PAUD educators in choosing games or developing forms of play for children. The game socialized in this activity is the Game of Integrity Shoots with the title "Keranjang Bolong". The Game of Integrity Shoots is one of the character education programs (anti-corruption) for the level of early childhood education (PAUD) which was developed by the Anti-Corruption Learning Center (ACLC) for Education and Community Services (Dikyanmas) of the Corruption Eradication Commission (KPK). This community service activity uses several methods, namely lecture method, demonstration method, and question and answer method. Through the socialization activities, participants get references on the types of games that can be used to stimulate the six aspects of child development and develop character education from an early age .
\end{abstract}

Keywords: Socialization, Game of Budding Integrity, Development of Early Childhood 


\section{Pendahuluan}

Anak usia dini yang berusia 0-8 tahun berada pada masa usia keemasan atau disebut golden age. Pada rentang usia ini, orangtua dan guru perlu menstimulasi semua aspek perkembangan anak agar anak tumbuh dan berkembang dengan optimal. Suyadi (2010:23-24) menyatakan bahwa kemampuan daya tangkap anak ketika berada pada usia keemasan adalah $80 \%$. Hal ini terjadi karena sinaps-sinaps pada otak anak saling menyambung untuk membentuk otak yang dahsyat.

Salah satu cara yang bisa dilakukan orangtua dan guru untuk menstimulasi semua perkembangan anak dengan baik adalah melalui bermain. Setiap anak senang bermain karena bermain adalah dunia anak. Menurut Moeslichatoen (dalam Simatupang, 2005), bermain merupakan suatu aktivitas yang menyenangkan bagi semua orang. Bermain akan memuaskan tuntutan perkembangan motorik, kognitif, bahasa, sosial, nilai- nilai dan sikap hidup seperti pendidikan karater. Oleh karena itu pendidik dan orangtua sebaiknya bisa menfasilitasi kebutuhan bermain pada anak usia dini.

Kenyataan yang banyak terjadi di lapangan adalah orangtua dan guru kurang menyadari bahwa melalui bermain ada banyak pengetahuan yang didapat oleh anak. Bermain adalah cara belajar anak usia dini untuk mengenal lingkungan sekitarnya, untuk tumbuh dan berkembang dengan baik, untuk mendapatkan pengalaman-pengalaman luar biasa sebagai pondasi masa depannya serta menstimulasi semua aspek-aspek perkembangan anak mulai dari kognitif, bahasa, fisik motorik, seni, moral-spiritual dan sosial emosional.

Bermain dapat dilakukan melalui media pembelajaran sebagai alat untuk menolong anak mengeksplorasi pengetahuan mereka.
Baik media pembelajaran yang di dalam dan di luar ruangan. Kegiatan bermain ini juga sebaiknya tidak hanya diperuntukkan kepada peserta didik dengan pertumbuhan normal, tetapi juga diperuntukkan bagi peserta didik yang mempunyai kebutuhan khusus. Anak berkebutuhan khusus adalah anak dengan karakteristik khusus yang berbeda dengan anak normal pada umumnya. Menurut Efendi (2013), istilah berkebutuhan khusus secara eksplisit ditujukan kepada anak yang dianggap mempunyai kelainan atau penyimpangan dari kondisi rata-rata anak normal umumnya yaitu dalam hal fisik, mental maupun karakteristik perilaku sosialnya. Bermain bagi anak berkebutuhan khusus itu membutuhkan pengaturan lingkungan secara khusus pula sehingga mereka dapat melakukan kegiatan bermainnya secara efektif. Hal ini menuntut pendidik PAUD untuk dapat berinovasi dalam memilih ataupun mengembangkan sebuah permainan.

Ada beberapa permainan yang memang diperuntukkan bagi anak dengan perkembangan normal dan anak dengan kebutuhan khusus yang dapat menstimulasi perkembangan pada anak dan pendidikan karakter. Salah satu permaian tersebut adalah Permainan Tunas Integritas. Permainan Tunas Integritas ini merupakan salah satu program pendidikan karakter (antikorupsi) untuk jenjang pendidikan anak usia dini (PAUD) yang dikembangkan AntiCorruption Learning Centre (ACLC) Pendidikan dan Pelayanan Masyarakat (Dikyanmas) Komisi Pemberantasan Korupsi (KPK) (Rachim, dkk, 2012). Yang akan disosialisasikan dalam pengabdian masyarakat Dosen Program Studi Pendidikan Guru PAUD Universitas PGRI Palembang, yaitu permainan Tunas Integritas "Keranjang Bolong”. Permainan Keranjang Bolong ini 
mengajarkan karakter jujur untuk anak PAUD. Di board game ini pemain diminta untuk tidak mengambil barang yang bukan haknya. Jika berhasil melakukannya maka dia yang akan menjadi pemenangnya.

Poin utama yang ingin diajarkan kepada anak-anak melalui game ini adalah pemahaman konsep kepemilikan barang. Disini anak boleh mengambil makanan dari keranjang lain untuk menyulitkan pemain lain, tapi esensi sebenarnya adalah jangan sembarangan mengambil dan menyimpan makanan atau barang yang bukan milik kita sendiri.

Mengingat pentingnya arti bermain bagi perkembangan anak usia dini dan penanaman karakter sejak dini, oleh karena itu dosen Program Studi Pendidikan Guru PAUD perlu melakukan "Sosialisasi Inovasi Media Pembelajaran Permainan Tunas Integritas Untuk Perkembangan Anak Usia Dini’.

Adapun tujuan diadakannya kegiatan pengabdian pada masyarakat ini adalah:

1. Melaksanakan Tri Dharma Perguruan Tinggi

2. Merealisasikan program kerja Program Studi Pendidikan Guru PAUD FKIP Universitas PGRI Palembang.

3. Memberikan Sosialisasi Permainan Tunas Integritas yang dapat menjadi inovasi bagi pendidik PAUD dalam memilih permainan ataupun mengembangkan bentuk permainan yang dapat menfasilitasi perkembangan anak dan menstimulasi pendidikan karakter anak didik sejak dini.

\section{Bahan dan Metode Pelaksanaan}

Kegiatan pengabdian kepada masyarakat ini dilaksanakan pada pada hari Kamis, 22 Maret 2018 dimulai pukul 08:00 WIB sampai dengan 12:00 WIB, bertempat di PAUD Kasih Bunda Yuliani Kecamatan Ilir Barat I.
Khalayak sasaran pada kegiatan pengabdian pada masyarakat ini yaitu Guru dan Pengelola PAUD Kecamatan Ilir Barat I yang berjumlah 48 orang

Kegiatan pengabdian ini akan dilaksanakan dengan beberapa metode sebagai berikut:

1) Metode Ceramah

Materi-materi yang diberikan dengan metode ceramah dengan menyajikan slide dalam bentuk power point.

2) Metode Demostrasi

Selain materi berupa teori, pemateri mendemostrasikan kegiatan praktek permainan tunas integritas, yang kemudian peserta diminta untuk mempraktekkan permainan tersebut di dalam kelompok-kelompok kecil.

3) Metode Tanya Jawab

Metode ini digunakan untuk menggali pemahaman peserta terhadap materi yang telah diberikan.

Pemateri pada kegiatan ini adalah dosen Program Studi Pendidikan Guru PAUD Universitas PGRI Palembang yang berjumlah 6 orang. Adapun bahan yang menjadi objek sosialisasi pada kegiatan pengabdian kepada masayarakat ini merupakan bentuk Permainan Tunas Integritas dari Komisi Pemberantasan Korupsi (KPK). Secara rinci materi yang disampaikan dapat dijelaskan melalui tabel berikut ini:

Tabel 1. Rincian Pemateri

\begin{tabular}{|c|l|l|}
\hline No & \multicolumn{1}{|c|}{ Nama } & \multicolumn{1}{c|}{ Judul Materi } \\
\hline 1 & $\begin{array}{l}\text { Romadona } \\
\text { Noverina } \\
\text { S.Pd., M.Si }\end{array}$ & $\begin{array}{l}\text { Perkembangan Anak } \\
\text { Usia Dini }\end{array}$ \\
\hline 2 & $\begin{array}{l}\text { Santa Idayana } \\
\text { Sinaga, M.Pd }\end{array}$ & $\begin{array}{l}\text { Bermain Bagi Anak } \\
\text { Usia Dini }\end{array}$ \\
\hline 3 & $\begin{array}{l}\text { Melinda } \\
\text { Puspita Sari } \\
\text { Jaya, M.Pd }\end{array}$ & $\begin{array}{l}\text { Media Pembelajaran } \\
\text { bagi Anak Usia Dini } \\
\text { dan Permainan Indoor }\end{array}$ \\
\hline 4 & $\begin{array}{l}\text { Febriyanti } \\
\text { Utami, M.Pd }\end{array}$ & $\begin{array}{l}\text { Permainan Outdoor } \\
\text { Anak Usia Dini }\end{array}$ \\
\hline 5 & Rahmah & Permainan Bagi Anak \\
\hline
\end{tabular}




\begin{tabular}{|c|l|l|}
\hline No & \multicolumn{1}{|c|}{ Nama } & \multicolumn{1}{c|}{ Judul Materi } \\
\hline & $\begin{array}{l}\text { Novianti, M. } \\
\text { Pd }\end{array}$ & Berkebutuhan Khusus \\
\hline 6 & Padilah, M.Pd & $\begin{array}{l}\text { Simulasi permainan } \\
\text { Tunas Integritas untuk } \\
\text { Anak Usia Dini }\end{array}$ \\
\hline
\end{tabular}

\section{Hasil dan Pembahasan}

Kegiatan pengabdian kepada masyarakat yang dilakukan di PAUD Kasih Bunda Yuliani Kecamatan Ilir Barat I ini menghasilkan modul dan luaran artikel ilmiah. Modul yang disusun mencakup definisi Perkembangan Anak Usia Dini, Bermain Bagi Anak Usia Dini, Media Pembelajaran Bagi Anak Usia Dini, Permainan Indoor dan Permainan Outdoor, Permainan Bagi Anak Berkebutuhan Khusus, serta Permainan Tunas Integritas Untuk Anak Usia Dini.

Modul tersebut telah dibagikan kepada peserta pelatihan sebagai panduan mengikuti kegiatan pengambdian kepada masyarakat yang dilaksanakan dan akan dipersentasikan oleh masing-masing pemateri. Selanjutnya kegiatan ini menghasilkan sebuah artikel ilmiah yang telah disusun oleh tim pelaksana berdasarkan laporan akhir hasil kegiatan pengabdian kepada masyarakat, lalu akan diajukan pada pengelola jurnal pengabdian kepada masyarakat yang ber-ISSN.

Sebelum persentasi oleh pemateri dimulai, kegiatan pengabdian kepada masyarakat ini dimulai dengan kegiatan pembukaan dengan memperkenalkan pihak Universitas dan pihak yang menjadi sasaran pada kegiatan pengabdian kepad masyarakat ini. Mengungkapkan maksud dan tujuan kegiatan pengabdian kepada masyarakat sebagai salah satu kegiatan Tri Dharma Perguruan Tinggi.

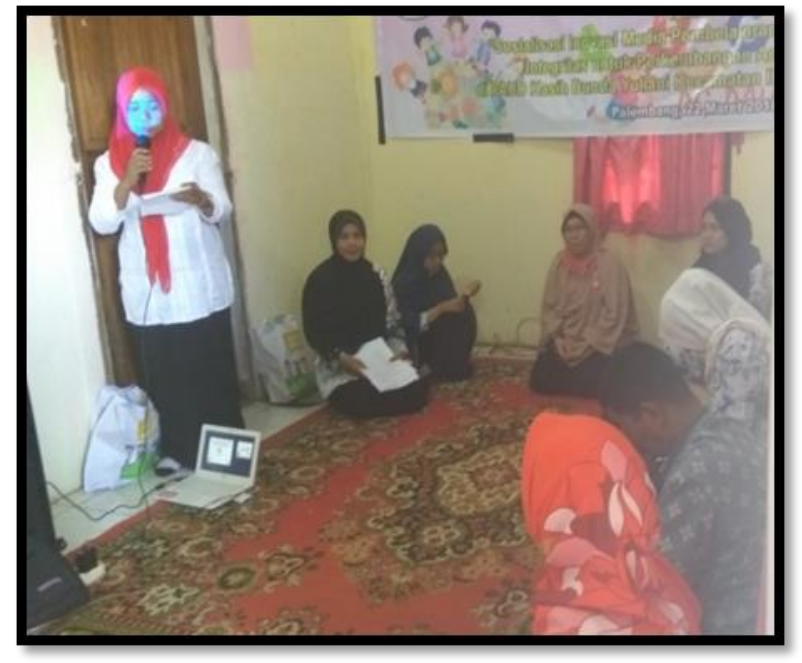

\section{Perkembangan Anak Usia Dini}

Materi pertama dengan judul Perkembangan Anak Usia Dini disampaikan oleh Romadona Noverina, S.Pd, M.Si. Pemaparan tentang Perkembangan Anak Usia Dini yang meliputi cakupan Hakikat Perkembangan Anak Usia Dini; Teori Pertumbuhan dan Perkembangan; Aspek Perkembangan Anak Usia Dini; dan Pola Perkembangan Anak.

Setelah pemaparan dilanjutkan dengan tanya-jawab. Metode ini dilakukan dengan terbuka dan suasana yang akrab, berbagi pengalaman dari tim dosen dan para peserta terkait perkembangan anak usia dini. Pertanyaan meliputi kiat-kiat dalam menstimulasi keenam aspek perkembangan pada anak usia dini.

\section{Bermain Bagi Anak Usia Dini}

Selanjutnya pemaparan kedua oleh Santa Idayana Sinaga, M.Pd dengan materi Bermain Anak Usia Dini. Pemaparan materi mengenai Perkembangan Anak Usia Dini meliputi, Defiisi Bemain Menurut Para Ahli; Mengapa Bermain Penting Untuk Dikembangkan?; dan Bagi Siapa Bermain Itu Penting Dilakukan?

Pemaparan dilanjutkan dengan diskusi seputar kegiatan bermain yang dapat diterapkan bagi anak usia dini khususnya 
dalam menstimulasi perkembangam anak usia dini dan pendidikan karakter. Tim dosen dan peserta pelatihan berbagi pengalaman mengenai jenis-jenis kegiatan bermain yang pernah diterapkan dalam proses pembelajaran.

\section{Media Pembelajaran Edukatif dan Permainan Indoor}

Pemaparan dilanjutkan pada sesi ketiga dengan materi Media Pembelajaran Edukatif dan Permainan Indoor oleh Melinda Puspita Sari Jaya, M.Pd. Dengan cakupan materi yang meliputi, Pengertian Media Permainan Edukatif dan Jenis Sarana Bermain Dalam Ruangan (Indoor).

Setelah pemaparan dilanjutkan dengan tanya jawab yang dilakukan bersifat terbuka dengan suasana yang akrab, tanya jawab seputar jenis-jenis alat main dalam (indoor) dan fungsi dari alat main dalam (indoor).

\section{Permainan Outdoor}

Materi keempat dilanjutkan setelah istirahat (coffee break) dengan materi Permainan Outdoor. Materi ini disampaiakn oleh Febriyanti Utami, M.Pd. Cakupan materi Permainan Outdoor ini meliputi, Pengertian Permainan Outdoor dan JenisJenis Alat Main Outdoor.

Setelah pemaparan oleh tim dosen, maka dilanjutkan dengan tanya jawab seputar alat main outdoor dan fungsinya dalam menstimulasi perkembangan anak usia dini

\section{Permainan Bagi Anak Berkebutuhan Khusus}

Materi selanjutnya mengenai Permainan Bagi Anak Berkebutuhan Khusus yang dipaparkan oleh Rahmah Novianti, M.Pd yang memang mempunyai keahlian pada bidang Anak Berkebutuhan Khusus.
Cakupan materinya meliputi, Bentuk Alat Main dan Jenis Permainan Yang Diperuntukkan Bagi Anak Dengan Kebutuhan Khusus.

Pemaparan dilanjutkan dengan tanya jawab mengenai materi yang disajikan. Pada materi ini peserta cukup antusias, karena dibeberapa lembaga mereka menemukan anak dengan indikasi memiliki kebutuhan khusus. Para peserta meminta kiat-kiat khusus terutama dengan menerapkan permaianan dalam menangani anak dengan kebutuhan khusus.

\section{Simulasi Permainan Tunas Integritas untuk Anak Usia Dini}

Pemaparan terakhir oleh Padilah, M.Pd dan dibantu oleh dua orang mahasiswa Program Studi Pendidikan Guru PAUD Universitas PGRI Palembang.

Pemateri mendemontrasikan kegiatan permaianan Tunas Integritas "Keranjang Bolong". Selanjutnya pemateri meminta peserta untuk membentuk kelompok kecil yang terdiri dari 6 orang. Kemudian peserta diminta untuk mempraktekkan permainan tersebut.

Keranjang bolong merupakan sebuah permainan tentang petualangan si kumbi di negara bernama kumbinasia. Tupi dan teman- temannya memasuki sebuah hutan, tanpa mereka ketahui keranjang yang mereka bawa itu bolong, dan bekal makanan mereka pun tercecer. Untuk melanjutkan perjalanan mereka harus mengumpulkan bekal makanan yang tercecer.

Permainan keranjang bolong di peruntukan untuk anak usia 4 s.d 7 tahun, tujuan permainan ini mencoba mengajarkan kepada anak untuk memahami konsep kepemilikan barang. Sebab, pada rentang usia tersebut, konsep kejujuran atas kepemilikan barang perlu ditanamkan dengan 
memahami mana yang menjadi hak dan mana yang bukan hak mereka.

\section{Komponen Permainan}

a. 1 buah papan (board) untuk permainan

b. 4 buah bidak karakter (Osi, Ayi, Tupi, Bimo)

c. 2 bidak karakter : 1 bidak positif (si Kumbi) dan 1 Bidak Negatif (Si Gala)

d. 1 buah dadu

e. 20 buah kartu hijau (Reward Card)

f. 15 kartu merah (Punisment Card)

g. 4 keranjang sesuai sesuai karakter (Osi, Ayi, Tupi, Bimo)

h. 16 buah jenis makanan yang terdiri atas wortel (4 Buah), Madu (4 Buah), Gabah padi (4 Buah), dan kacang (4 Buah).

\section{Langkah Permainan}

1) Buka dan susun board game permainan

2) Susun kartu merah dan hijau di tempat yang telah disediahkan di tengah papan permainan

3) Tempatkan 4 bidak karakter (Osi, Ayi, Tupi, Bimo) di garis star

4) Tempatkan jenis- jenis makanan di sepanjang track sesuai dengan simbol makanan tersebut

5) Tempatkan bidak si kumbi dan si gala secara acak di sepanjang track

6) Pemain di minta untuk memilih karakter, setelah dilakukan hompimpah untuk menandakan siapa yang memulai pertama

7) Permainan siap di mulai.

\section{Aturan Permainan}

1) Sebelum permainan di mulai, semua pemain diberikan waktu untuk membaca dan mempelajari cerita yang menjadi gambaran setting cerita dan mempelajari cerita yang menjadi setting cerita dalam permainan, atau fasilitator bisa membacakan aturan permainannya.
2) Setelah di minta untuk memilih karakter, pemain melakukan hompimpah untuk menentukan siapa jalan pertama

3) Setelah di tentukan siapa jalan pertama, maka pemain pertama berhak untuk melempar dadu dan menjalankan bidak sesuai dengan jumlah angka atau titik yang muncul di permukaan dadu. Hal ini dilakukan secara berurutan kepada semua peserta permainan. Arah putaran bidak sesuai dengan arah jarum jam.

4) Setelah semua mendapatkan giliran menjalankan bidak, maka giliran fasilitator untuk menjalankan bidak si kumbi dan sigala sesuai dengan angka dadu, tetapi arahnya berlawanan dengan jarum jam.

5) Ketika bidak jatuh pada gambar yang sesuai dengan jenis makanannya, maka pemain boleh mengambil makanan yang tercecer. Tetapi jika tidak sesuai dengan makannya, maka tidak boleh mengambil makanan tersebut.

6) Jika bidak si kumbi jatuh atau satu kotak dengan pemain aktif, maka pemain tersebut berhak mengambil kartu hijau (Reward card) untuk dibacakan kemudian mengikuti petunjuk yang tertera pada kartu hijau.

7) Jika bidak si gala jatuh atau satu kotak dengan pemain aktif, maka pemain tersebut berhak mengambil kartu merah (Punisment card) untuk dibacakan kemudian mengikuti petunjuk yang tertera pada kartu merah.

8) Pemain yang paling cepat mengumpulkan jenis makanan yang sesuai (4 buah), maka pemain tersebut dinyatakan sebagai pemenang. 


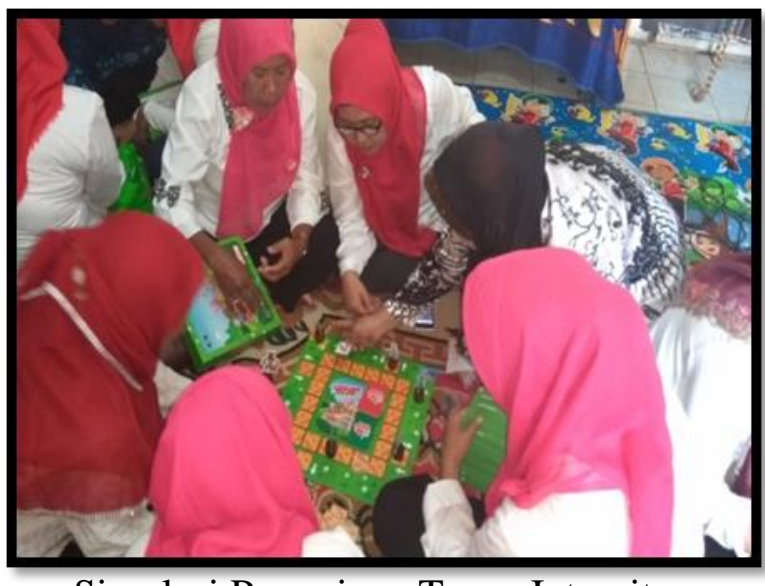

Simulasi Permainan Tunas Integritas "Keranjang Bolong"

Peserta terlihat sangat antusias dalam mempraktekkan permainan Keranjang Bolong. Terlebih lagi pemateri menyediakan hadiah bagi kelompok yang menang atau lebh dahulu dalam menyelesaikan permaianan.

Setelah kegiatan simulasi permaianan berakhir, kegiatan dilanjutkan dengan tanya jawab terkait dengan Permaianan Tunas Integritas.

\section{Evaluasi}

Kegiatan diakhiri dengan evaluasi an, peserta sosialisasi pada kegiatan pengabdian kepada masyarakat ini diminta untuk mengisi beberapa pertanyaan seputar materi yang telah disampaikan. Peserta diminta pula untuk menyampikan kritik dan saran terhadap kegiatan yang telah dilaksanakan sebagai bahan kajian dan perbaikan diri bagi pemateri.

Berdasarkan evaluasi pelaksanaan dan hasil kegiatan dapat diidentifikasi faktor pendukung dan penghambat dalam melaksanakan program pengabdian kepada masyarakat ini. Secara garis besar faktor pendukung dan penghambat adalah sebagai berikut :

\section{a. Faktor Pendukung}

Yang menjadi faktor pendukung pada kegiatan PKM ini yaitu antusiasme dan keaktifan para peserta dalam mengikuti Sosialisasi Inovasi Media Pembelajaran Permainan Tunas Integritas Untuk Perkembangan Anak Usia Dini PAUD Kasih Bunda Yuliani Kecamatan Ilir barat I yang diadakan serta dukungan dari Yayasan Kasih Bunda Yuliani, HIMPAUDI Kecamatan Ilir Barat I, dan Universitas PGRI Palembang yang menyambut baik pelaksanaan kegiatan sosialisasi ini dan membantu TIM PKM Program Studi Pendidikan Guru PAUD dalam mengorganisasikan waktu dan tempat pelasanaan kegiatan.

Selain itu, faktor pendukung lainnya diperoleh dari Direktur Pendikan dan Pelayanan Masyarakat (Dikyanmas) KPK RI yang telah memberi dukungan dalam bentuk buku-buku dongeng yang dapat dibagikan kepada peserta yang hadir.

\section{b. Faktor Penghambat}

Yang menjadi faktor penghambat dalam Kegiatan PKM ini yaitu keterbatasan waktu dalam pelaksanan kegiatan sosialiasi ini, sehingga pada kegiatan simulasi permainan tunas integritas hanya dilakukan satu kali putaran permianan saja. Padahal peserta kegiatan PKM sangat antusias dalam melaksanakan permainan tunas integritas “Keranjang Bolong” yang dipraktekkan.

\section{Penutup}

Sosialisasi menegnai Permainan Tunas Integritas "Keranjang Bolong" bagi Kepala Sekolah, Guru dan Pengelola di Kecamatan Ilir Barat I dapat terselenggara dengan baik dan berjalan dengan lancar sesuai dengan rencana kegiatan yang telah dibuat. Kegiatan ini mendapat sambutan yang sangat baik, terllihat dari antusias dan keaktifan peserta 
dalam mengikuti kegiatan sosialisasi dengan tidak meninggalkan tempat sebelum waktu sosialisasi pelatihan berakhir.

Kegiatan sosialisasi ini sangat memberikan manfaat untuk menambah pengetahuan mengenai Permainan Tunas Integritas Bagi Anak Usia Dini yang sangat dibutuhkan bagi Kepala Sekolah, Guru dan Pengelola sebagai salah satu alternatif dalam kegiatan permainan yang bisa diterapkan di lembaga-lembaga PAUD. Melihat manfaat dari kegiatan ini, diharapkan kegiata PKM ini dapat dilaksanakan secara rutin.

\section{Daftar Pustaka}

Suyadi. 2010. Psikologi Belajar PAUD. Yogyakarta: Pedagogia.

Simatupang, Nurhayati. 2005. Bermain Sebagai Upaya Dini Menanamkam Aspek Sosial Bagi Siswa Sekolah Dasar. Jurnal Pendidlkan Jasmani Indonesia, Volume 3, Nomor 1.

Efendi, M. 2006. Pengantar Psikopedagogik Anak Berkelainan. Jakarta: Bumi Aksara.

Rachim, Dedie A. dkk. 2012. Agar Tunas Itu Tumbuh Berkembang: Panduan Penggunaan Seri Tunas Integritas Jakarta: KPK RI. 